\title{
ANALISIS PEMBIAYAAN DAN KREDIT SEKTOR KONSTRUKSI DI INDONESIA: STUDI PERBANKAN SYARIAH DAN KONVENSIONAL
}

(Analysis of Financing and Credit on Construction Sector in Indonesia: Study of Islamic and Conventional Banking)

\author{
Nidaa Nazaahah Kusumawati ${ }^{1}$, Nunung Nuryartono ${ }^{2}$, Irfan Syauqi Beik ${ }^{2}$ \\ ${ }^{1}$ Mahasiswa Program Magister Ilmu Ekonomi, FEM IPB \\ ${ }^{2}$ Staff Pengajar FEM IPB
}

\begin{abstract}
The construction sector is an important sector in supporting development projects in Indonesia. The development of the construction sector requires the role of the banking sector to provide access of capital through credit or financing. This study aims to analyze the factors affecting construction financing and credit in Islamic and Conventional Banking in Indonesia and among regions in Indonesia. This study uses Vector Autoregression/Vector Error Correction Model (VAR/VECM) with monthly data from 2006 until 2014 and panel data analysis with yearly data from 2009 until 2013. The study results that the factors affecting financing and credit on Construction Sector in Indonesia are Third Party Funds (DPK), Wholesale price index, fee of SBIS (interest rate of SBI), percentage of Non Performing Financing (Non Performing Loan), Consumer Price Index and equivalent rate of financing (Interest rate of Credit). Furthermore, the factors affecting financing and credit on Construction Sector among regions in Indonesia are Third Party Funds, Gross Domestic Regional Product of Construction Sector, Gross Domestic Regional Product per Capita and percentage of Non Performing Financing (Non Perfoming Loan).
\end{abstract}

Keywords: Construction, Credit, Financing, Panel data, VAR/VECM.

\section{PENDAHULUAN}

\section{Latar Belakang}

Sektor konstruksi merupakan salah satu sektor penting dalam mendukung pembangunan ekonomi di Indonesia dan berperan dalam menggerakkan sektor riil yang secara langsung menyangkut kehidupan orang banyak. Selain itu, sektor konstruksi merupakan sektor yang inamis dan dapat memberikan multiplier effect yang berguna dalam peningkatan kesejahteraan, baik secara langsung melalui penciptaan lapangan pekerjaan maupun tidak langsung melalui kontribusi terhadap PDB nasional
(Mallick dan Mahalik 2008). Sektor konstruksi memberi-kan kontribusi sebesar $10,34 \%$ terhadap struktur pendapatan domestik bruto (BPS 2016). Nilai PDB sektor konstruksi berdasarkan harga konstan 2010 pada tahun 2015 yaitu sebesar 881,6 triliun rupiah dengan laju pertumbuhan $6,65 \%$. Selain itu, sektor konstruksi berkontribusi dalam menyerap tenaga kerja sebesar 7,28 juta jiwa.

Pencapaian kondisi pembangunan sektor konstruksi dan infrastruktur yang optimal memerlukan kontribusi dan dukungan dari pemerintah dan seluruh masyarakat Indonesia beserta seluruh aspek kelembagaan. Salah satu pihak 
yang memiliki peran terhadap sektor konstruksi yaitu sektor perbankan. Perbankan berperan dalam memberikan bantuan modal untuk sektor-sektor riil di Indonesia melalui penyaluran dana berupa kredit atau pembiayaan. Pada Gambar 1 menunjukkan terjadi peningkatan jumlah pembiayaan dan kredit pada sektor konstruksi di Indonesia.

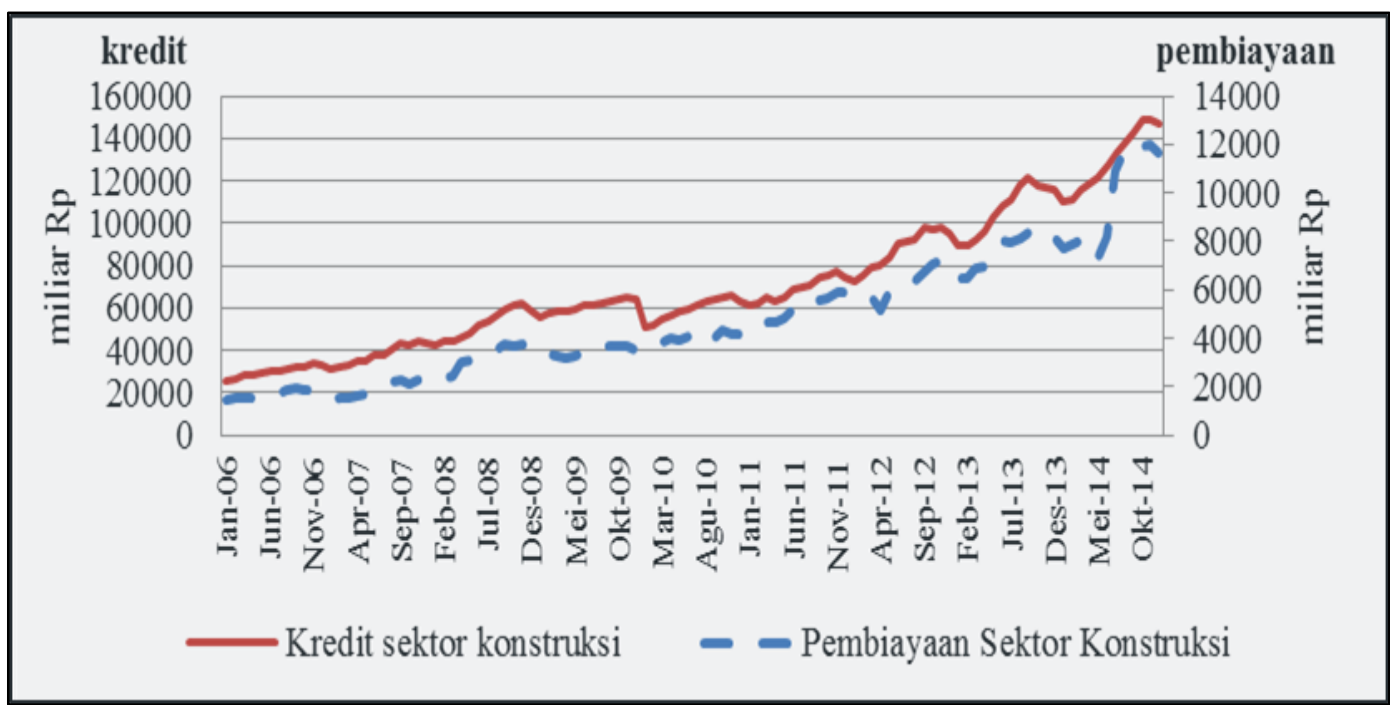

Sumber: SPI-BI dan SPS-BI (2015)

Gambar 1 Jumlah pembiayaan dan kredit sektor konstruksi

Faktor-faktor yang mempengaruhi besarnya pembiayaan pada sektor konstruksi dapat berasal dari kondisi internal maupun kondisi eksternal perbankan. Menurut Pohan (2008) dan Nugroho (2009) perilaku penawaran pembiayaan ataupun kredit perbankan dipengaruhi oleh suku bunga, persepsi bank terhadap prospek usaha debitur dan kondisi internal perbankan itu sendiri seperti tercermin pada permodalan atau Capital Adequacy Ratio (CAR), jumlah kredit macet atau Non Performing Loan (NPL), dan Loan to Deposit Ratio (LDR) (Widyastuti dan Anwar, 2009).

\section{Perumusan Masalah}

Sektor konstruksi memiliki peran penting dalam membangun infrastruktur dalam rangka meningkatkan produktivitas, kesempatan kerja dan laju perekonomian. Pengembangan sektor kon-struksi perlu mendapat dukungan dari sektor perbankan. Namun, data Bank Indonesia menunjukkan bahwa rasio pembiayaan (kredit) sektor konstruksi terhadap total pembiayaan (kredit) cenderung mengalami penurunan semenjak akhir tahun 2008 (Gambar 2). 


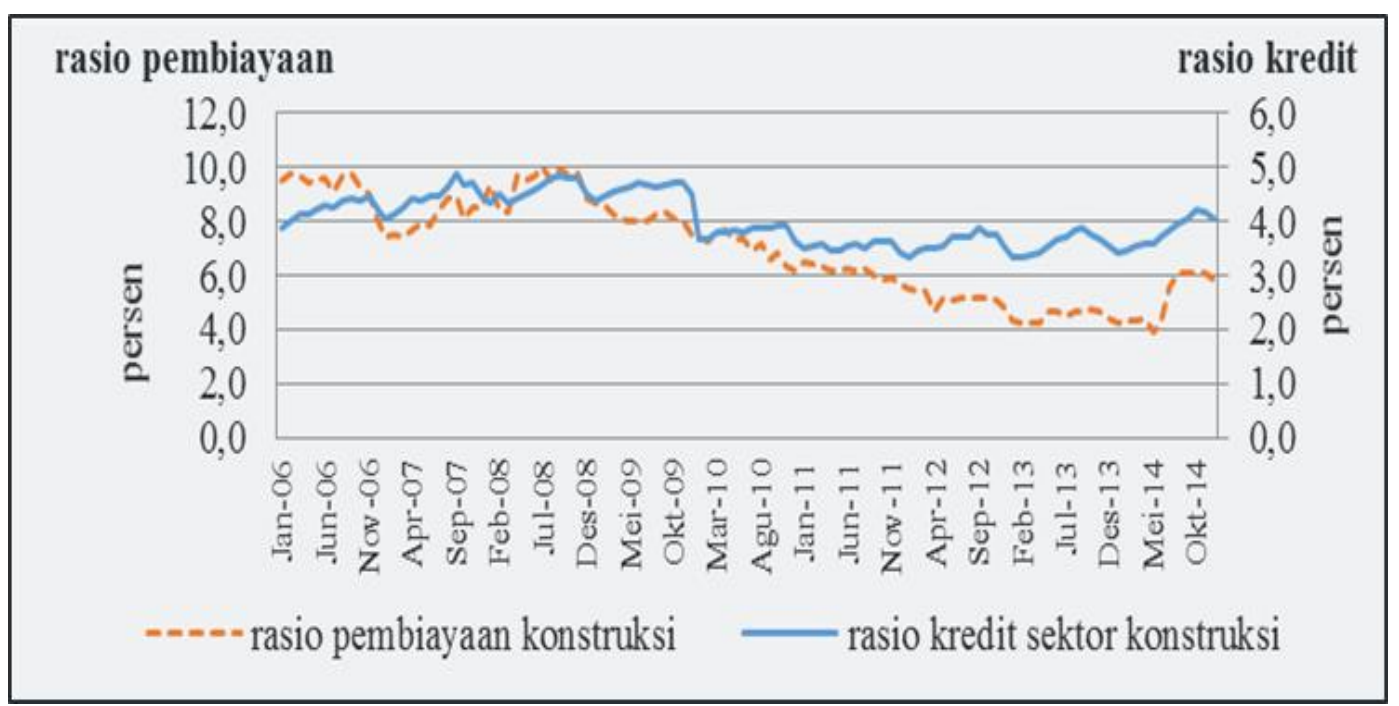

Sumber: Statistik Perbankan Indonesia - Bank Indonesia (2015)

Gambar 2 Rasio pembiayaan dan kredit sektor konstruksi

Selain itu, bila dilihat dari biayaan dan kredit untuk sektor penyaluran pembiayaan dan kredit konstruksi masih terpusat di wilayah sektor konstruksi pada 33 provinsi di Jawa, khususnya di DKI Jakarta Indonesia, terlihat bahwa jumlah pem- (Gambar 3).

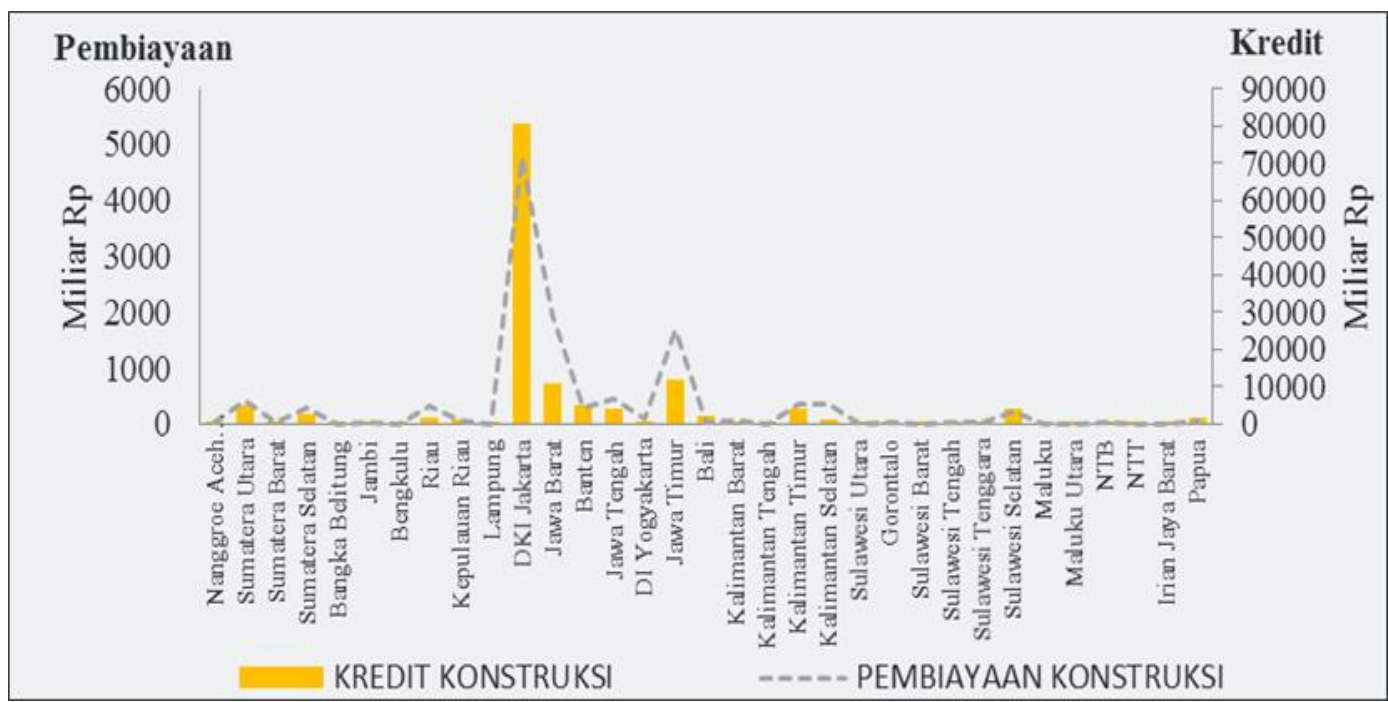

Sumber: Statistik Perbankan Indonesia - Bank Indonesia (2015)

Gambar 3 Jumlah pembiayaan dan kredit sektor konstruksi berdasarkan wilayah penyaluran

Berdasarkan uraian latar belakang dan perumusan masalah, maka dirasa penting untuk melakukan analisis mengenai faktor internal maupun eksternal perbankan yang diduga dapat menyebabkan terjadinya penurunan rasio pembiayaan dan kredit sektor konstruksi di Indonesia dan faktorfaktor yang memengaruhi penyaluran pembiayaan dan kredit sektor konstruksi antar wilayah di Indonesia. Secara khusus dapat dirumuskan beberapa permasalahan dalam rincian sebagai berikut: 
1. Faktor-faktor apa sajakah yang memengaruhi pembiayaan dan kredit sektor konstruksi pada perbankan syariah dan perbankan konvensional di Indonesia?

2. Faktor-faktor apa sajakah yang memengaruhi pembiayaan dan kredit sektor konstruksi antar wilayah di Indonesia?

\section{Tujuan Penelitian}

Dari perumusan masalah yang telah diuraikan di atas, maka tujuan penelitian ini adalah sebagai berikut:

1. Menganalisis faktor-faktor yang memengaruhi pembiayaan dan kredit sektor konstruksi pada perbankan syariah dan konvensional di Indonesia.

2. Menganalisis faktor-faktor yang memengaruhi pembiayaan dan kredit sektor konstruksi antar wilayah di Indonesia.

\section{TINJAUAN PUSTAKA}

\section{Perbedaan Pembiayaan dan Kredit Perbankan}

Fungsi utama bank adalah untuk memberikan jasa kepada masyarakat, baik berupa penyimpanan dana maupun penyaluran dana kepada masyarakat. Terdapat perbedaan antara sistem pemberian kredit bank konvensional dan pembiayaan bank syariah. Perbedaan tersebut antara lain terletak pada akad atau perjanjian, pembagian keuntungan, dan besarnya prosentase dana yang harus dikembalikan oleh debiturnya.

Pada Bank syariah tidak menggunakan istilah pinjaman atau kredit yang identik dengan bunga dalam aktifitas usahanya, melainkan menggunakan istilah pembiayaan. Pembiayaan atau financing, yaitu pendanaan yang diberikan oleh suatu pihak kepada pihak lain untuk mendukung investasi yang telah direncanakan baik dilakukan sendiri maupun lembaga. Dengan kata lain pembiayaan adalah pendanaan yang dikeluarkan oleh lembaga pembiayaan seperti bank syariah kepada nasabah (Muhammad, 2005).

Baik bank konvensional maupun bank syariah mempunyai peraturan masing-masing untuk menetapkan dan mengatur pemberian kredit dan pembiayaan maupun jasa perbankan lainnya. Akan tetapi peraturan yang ditetapkan harus berpedoman pada peraturan perbankan yang berlaku secara umum.

Sistem pemberian kredit pada bank konvensional lebih menekankan pada perolehan bunga yang ditetapkan pada para debitur. Besarnya jumlah peng-embalian pinjaman yang harus dibayarkan oleh para debitur adalah sebesar jumlah pinjaman kredit yang diterima beserta jumlah bunga kredit yang ditetapkan pihak bank. Sehingga dengan adanya bunga tersebut dapat dimasukkan dalam pendapatan dan keuntungan bank.

Jika dipandang dari segi syariah, maka apa yang diterapkan pada bank konvensional tersebut adalah termasuk perbuatan riba. Sementara itu, sistem pembiayaan yang diterapkan pada bank syariah memiliki beberapa perbedaan dengan sistem pemberian kredit yang diterapkan pada bank konvensional.

Ketika terdapat debitur yang meminjam dana kepada bank syariah, maka antara pihak bank maupun pihak debitur akan melakukan perjanjian diawal pembiayaan yang dianggap sebagai pengikatan kontrak antara pihak bank dengan calon nasabah atau calon debitur. Perjanjian tersebut meliputi perhitungan bagi hasil yang akan ditanggung bersama oleh kedua pihak tersebut. Berdasarkan hasil keputusan MUI (Majelis Ulama Indonesia), bagi 
hasil tersebut bukan merupakan aktivitas riba dan tidak haram. Menurut Karim, dalam menyalurkan dananya ke nasabah secara garis besar produk pembiayaan syariah terbagi menjadi:

1. Pembiayaan dengan prinsip jual beli yang terdiri dari pembiayaan dengan akad murabahah, salam, dan istishna.

2. Pembiayaan dengan prinsip sewa menggunakan akad ijarah.

3. Pembiayaan dengan prinsip bagi hasil yang terdiri dari pembiayaan dengan akad musyarakah dan mudharabah.

4. Pembiayaan dengan prinsip akad lainnya yang terdiri dari hiwalah (alih piutang), rahn (gadai), qardh, wakalah (perwakilan), dan kafalah (garansi).

\section{Teori Dasar Kredit}

Dalam teori klasik yang dikutip dari Boediono (1998), bunga adalah harga dari loanable funds (dana investasi). Teori ini dikembangkan oleh kelompok ekonom klasik pada abad 19. Tingkat bunga adalah salah satu indikator dalam memutuskan apakah seseorang akan menabung atau melakukan investasi. Makin tinggi tingkat bunga, makin banyak dana yang ditawarkan. Dengan demikian, terdapat hubungan positif antara tingkat bunga dengan jumlah dana yang ditawarkan (Boediono, 1998). Pada prinsipnya, tingkat bunga adalah harga yang harus dibayarkan atas penggunaan dana untuk setiap unit waktu yang telah ditentukan melalui interaksi permintaan dan penawaran.

Permintaan akan loanable fund memiliki hubungan negatif dengan tingkat bunga. Dengan asumsi pendapatan dan faktor-faktor lainnya konstan, peningkatan tingkat bunga akan menurunkan permintaan terhadap dana peminjaman (loanable fund). Asumsi-asumsi tersebut berlaku dalam perekonomian dalam keadaan full employment, harga konstan, supply of money tetap, dan informasi sempurna.

\section{Mekanisme Kebijakan Moneter}

Mekanisme kebijakan moneter menggambarkan tindakan Bank Indonesia melalui perubahan-perubahan instrumen moneter dan target operasionalnya dalam memengaruhi berbagai variabel ekonomi dan keuangan. Mekanisme tersebut terjadi melalui interaksi antara Bank Sentral, perbankan dan sektor keuangan, serta sektor riil. Perubahan BI Rate memengaruhi inflasi melalui berbagai jalur, diantaranya jalur suku bunga, jalur kredit, jalur nilai tukar, jalur harga aset, dan jalur ekspektasi (BI, 2015).

Pada jalur suku bunga, perubahan BI Rate memengaruhi suku bunga deposito dan suku bunga kredit perbankan. Apabila perekonomian sedang mengalami resesi, Bank Indonesia dapat menggunakan kebijakan moneter yang ekspansif melalui penurunan suku bunga untuk mendorong aktifitas ekonomi. Penurunan suku bunga kredit juga akan menurunkan biaya modal perusahaan untuk melakukan investasi. Ini semua akan meningkatkan aktifitas konsumsi dan investasi sehingga aktifitas perekonomian semakin meningkat. Sebaliknya, apabila tekanan inflasi mengalami kenaikan, Bank Indonesia merespon dengan menaikkan suku bunga BI Rate untuk mencegah aktifitas perekonomian yang terlalu cepat sehingga mengurangi tekanan inflasi (BI 2015).

Mekanisme transmisi kebijakan moneter melalui jalur kredit, dapat dijelaskan sebagai berikut: BI rate $\downarrow \rightarrow$ 
Interbank rate $\downarrow \rightarrow$ Deposit rate $\downarrow \rightarrow$ Loan rate $\downarrow \rightarrow$ Bank Loan $\uparrow \rightarrow \mathrm{Y} \uparrow$.

\section{Faktor-Faktor yang Memengaruhi Pembiayaan dan Kredit Sektor Konstruksi di Indonesia}

Faktor-faktor yang memengaruhi besarnya pembiayaan ataupun kredit pada sektor konstruksi dapat berasal dari kondisi internal (kinerja perbankan) maupun kondisi eksternal perbankan (Reed, 1989).

\section{Kategori Kinerja Perbankan}

Kinerja perbankan yang digunakan dalam penelitian tentang faktor-faktor yang memengaruhi pembiayaan dan kredit sektor konstruksi di Indonesia mencakup Dana Pihak Ketiga (DPK) dan Non Performing Financing/Loan (NPF/NPL).

Dana Pihak Ketiga adalah dana yang berasal dari masyarakat luas yang merupakan sumber dana terpenting bagi kegiatan operasional suatu bank. Sumber dana ini merupakan sumber dana terpenting bagi kegiatan operasional bank dan merupakan ukuran keberhasilan bank jika mampu membiayai operasionalnya dari sumber dana ini (Kasmir, 2008). Masyarakat mempercayakan dananya kepada bank berdasarkan perjanjian penyimpanan dana dalam bentuk giro, deposito, sertifikat deposito, tabungan dan atau bentuk lainnya yang dipersamakan dengan itu.

Pada perbankan syariah dana simpanan yang dipercayakan oleh nasabah kepada bank syariah dapat berdasarkan akad wadi'ah atau akad lain yang tidak bertentangan dengan prinsip syariah dalam bentuk giro dan tabungan. Sementara dana investasi yang dipercayakan oleh nasabah kepada bank syariah dapat berdasarkan akad mudharabah atau akad lain yang tidak bertentangan dengan prinsip syariah dalam bentuk deposito, tabungan, dan bentuk lain yang dapat dipersamakan dengan itu (Soemitra, 2009).

Pembiayaan bermasalah dalam perbankan syariah dikenal dengan istilah Non Performing Financing sedangkan pada perbankan konvensional dikenal dengan istilah Non Performing Loan. Menurut Kasmir (2008) Non Performing Loan atau Non Performing Financing adalah presentase jumlah pembiayaan bermasalah terhadap total pembiayaan yang dikeluarkan bank. NPF merupakan rasio keuangan yang digunakan sebagai indikator terhadap nilai dari suatu risiko kredit atau pembiayaan. Rasio ini menunjukkan kemampuan manajemen bank dalam mengelola kredit bermasalah.

Kriteria yang termasuk dalam NPF menurut Bank Indonesia adalah pembiayaan kurang lancar, diragukan, dan macet. NPF sangat berpengaruh terhadap pengendalian biaya dan kebijakan pembiayaan yang dilakukan oleh bank itu sendiri. Menurut Syafii (2001) pengendalian biaya mempunyai hubungan terhadap kinerja lembaga perbankan. Peningkatan NPF akan berpengaruh terhadap peningkatan jumlah Penyisihan Aktiva Produktif (PPAP) yang harus dibentuk oleh pihak bank syariah sesuai ketentuan dari Bank Indonesia. Bila hal ini berlangsung terus menerus maka akan mengurangi modal bank syariah sehingga akan berpengaruh terhadap kemampuan bank dalam menyalurkan pembiayaan. Besarnya NPF dapat dirumuskan sebagai berikut:

$N P F=\frac{\text { pembiayaan bermasalah }}{\text { total pembiayaan }} \times 100 \%$

\section{Kondisi Makroekonomi}

Variabel yang digunakan dalam penelitian ini yang termasuk dalam 
kategori kondisi makroekonomi yaitu Indeks Harga Konsumen (IHK) dan Indeks Harga Perdagangan Besar Bangunan/ Konstruksi (IHPB)

Indeks Harga Konsumen adalah Indeks yang menghitung rata-rata perubahan harga dari suatu paket barang dan jasa yang dikonsumsi oleh rumah tangga dalam kurun waktu tertentu (BPS). IHK merupakan indikator yang digunakan untuk mengukur tingkat inflasi. Perubahan IHK dari waktu ke waktu menggambarkan tingkat kenaikan (inflasi) atau tingkat penurunan (deflasi) dari barang dan jasa.

Indeks Harga Perdagangan Besar Bangunan/ Konstruksi Indeks Harga Perdagangan Besar (IHPB) adalah indikator yang menggambarkan besarnya perubahan harga di tingkat pedagang besar/harga grosir dari komoditi yang diperdagangkan di suatu negara/daerah. Komoditi tersebut merupakan hasil produksi dalam negeri yang dipasarkan di dalam negeri atau diekspor, dan komoditi yang diimpor dari luar negeri. IHPB digunakan sebagai proksimasi dari kondisi sektor konstruksi di Indonesia.

\section{Instrumen Moneter}

Variabel instrumen moneter yang digunakan dalam penelitian ini adalah Sertifikat Bank Syariah (BSBIS). Berdasarkan Peraturan BI Nomor 10/11/PBI tanggal 31 Maret 2008 tentang Sertifikat Bank Indonesia Syariah (SBIS). SBIS adalah surat berharga berdasarkan Prinsip Syariah berjangka waktu pendek dalam mata uang rupiah yang diterbitkan oleh Bank Indonesia. SBIS menggunakan akad ju'alah dan berdasarkan fatwa Dewan Syariah Nasional-Majelis Ulama Indonesia, SBIS juga dapat diterbitkan dengan menggunakan akad mudharabah, musyarakah, wadiah, qardh, dan wakalah. Bank Indonesia memberikan imbalan atas SBIS yang diterbitkan yang disebut dengan Bonus Sertifikat Bank Syariah (BSBIS). Istilah SBIS mulai berlaku sejak tahun 2008. Sebelumnya dikenal dengan istilah Sertifikat Wadiah Bank Indonesia (SWBI) yang merupakan bukti penitipan dana wadiah, yaitu penitipan dana berjangka pendek dengan menggunakan prinsip wadiah yang disediakan oleh Bank Indonesia bagi BUS dan UUS. Sertifikat Bank Indonesia (SBI) Sertifikat Bank Indonesia (SBI) adalah surat berharga yang dikeluarkan oleh Bank Indonesia sebagai pengakuan utang berjangka waktu pendek (1-3 bulan) dengan sistem diskonto/bunga. SBI merupakan salah satu mekanisme yang digunakan Bank Indonesia untuk mengontrol kestabilan nilai Rupiah.

\section{Variabel Rate of Return}

Variabel Rate of Return yang digunakan dalam penelitian meliputi Equivalent Rate Pembiayaan, Suku Bunga Kredit, Equivalent rate dalam Statistik Perbankan Syariah (SPS) OJK adalah indikasi tingkat imbalan dari suatu penanaman dana atau nisbah bagi hasil dari pembiayaan perbankan syariah.

Suku Bunga Kredit menurut Kasmir (2008) diartikan sebagai balas jasa yang diberikan oleh nasabah pada bank yang berdasarkan prinsip konvensional. Imbal jasa ini merupakan suatu kompensasi kepada pemberi pinjaman atas manfaat ke depan dari uang pinjaman tersebut apabila diinvestasikan. Jumlah pinjaman tersebut disebut "pokok utang" (principal). Persentase dari pokok utang yang dibayarkan sebagai imbal jasa (bunga) dalam suatu periode tertentu disebut "suku bunga". 


\section{Kajian Penelitian Terdahulu}

Penelitian tentang penyaluran pembiayaan dan kredit perbankan telah banyak dilakukan, namun belum banyak yang memfokuskan pada sektor konstruksi. Maka penelitian ini akan menganalisis mengenai faktor-faktor yang memengaruhi jumlah pembiayaan pada sektor konstruksi oleh perbankan syariah dan membandingkannya dengan faktor-faktor yang memengaruhi jumlah kredit pada perbankan konvensional. Selain itu penelitian ini akan menganalisis faktor-faktor yang mempengaruhi pembiayaan dan kredit sektor konstruksi antar wilayah di Indonesia.

Beberapa penelitian yang menjadi acuan dalam penelitian ini yaitu antara lain mengenai peran sektor konstruksi terhadap pertumbuhan ekonomi di India (Mallick dan Mahalik, 2008), menggunakan pendekatan ECM cointegration dan ARDL cointegration. Penelitian ini menunjukkan bahwa sektor konstruksi dapat berpengaruh terhadap pertumbuhan ekonomi melalui peningkatan jumlah pekerja dan peningkatan agregat output dalam perekonomian.

Ozcusa dan Akbostanci (2012) menganalisis penyaluran pembiayaan dan kredit oleh bank di Turki, untuk melihat dampak perubahan kebijakan moneter dalam perilaku penyaluran kredit perbankan. Periode penelitian dibagi menjadi dua sub periode untuk melihat dampak perubahan kebijakan dan kondisi sistem keuangan akibat krisis 2000 hingga 2001 terhadap penyaluran kredit. Sub-periode pertama yaitu dari tahun 1988 hingga 2001 dan sub-periode kedua yaitu dari tahun 2002 hingga 2009. Metode yang digunakan dalam penelitian ini yaitu panel dinamis, dengan variabel indikator antara lain ukuran, likuiditas, kapitalisasi, kualitas aset, pendapatan, dan kemampuan serta efisiensi manajemen perbankan. Hasil penelitian menunjukkan bahwa terdapat perbedaan signifikan perilaku penyaluran kredit pada periode sebelum dan sesudah krisis.Variabel PDB riil memiliki hubungan signifikan positif terhadap kredit perbankan. Tingkat inflasi memiliki hubungan signifikan negatif, yang tidak sesuai dengan hipotesis awal. Kualitas aset, kapitalisasi, dan likuiditas menunjukkan hubungan signifikan positif terhadap penyaluran kredit, dan ukuran memiliki hubungan negatif terhadap tingkat pertumbuhan kredit. Hasil penelitian menunjukkan dampak yang jauh lebih kuat dari perubahan kebijakan moneter pada tingkat pertumbuhan kredit terjadi pada periode 2002 hingga 2009. Hal ini dikarenakan setelah krisis keuangan 2000-2001, telah ada sejumlah perubahan regulasi dan struktural yang signifikan di sektor perbankan Turki.

Barajas et al. (2010) melakukan penelitian mengenai stagnasi kredit di wilayah MENA (Middle East and North Africa). Penelitian ini menggunakan metode balanced panel data dengan data tahunan dari sebelas negara di kawasan MENA pada tahun 1997 hingga 2008. Hasil analisis menunjukkan bahwa pertumbuhan deposito, pertumbuhan net interest margin, cost income ratio dan aset bank berpengaruh positif terhadap pertumbuhan kredit sementara pembiayaan tidak lancar berpengaruh negatif terhadap pertumbuhan kredit. Selain itu, dalam penelitian ini ditemukan bahwa bank syariah memiliki kecenderungan untuk meningkatkan penyaluran kredit lebih besar daripada bank komersial dan bank investasi. Sementara kondisi makroekonomi yaitu pertumbuhan GDP riil 
dan harga minyak (pada negara eksportir minyak) berpangaruh positif terhadap pertumbuhan kredit.

Poghosyan (2010) menganalisis faktor-faktor yang mempengaruhi perlambatan kredit dari sisi permintaan dan penawaran di Jordania periode 1999 sampai dengan 2010. Penelitian ini menggunakan model disequilibrium framework untuk melihat apakah penurunan jumlah kredit yang disalurkan disebabkan oleh berkurangnya penawaran kredit, berkurangnya permintaan kredit atau keduanya. Hasil analisis menunjukkan bahwa faktorfaktor yang memengaruhi penawaran kredit yaitu suku bunga, indeks saham Amman, diferensial antara CBJ (Central Bank of Jordan) re-discount rate dan US FED fund rate berpengaruh negatif terhadap penawaran kredit, sementara indeks produksi industri dan lending capacity yang berpengaruh positif terhadap penawaran kredit. Dari sisi permintaan, suku bunga dan indeks produksi industri berpengaruh positif terhadap permintaan kredit, indeks saham Amman berpengaruh negatif terhadappermintaan kredit serta efek dari perang irak tidak berpengaruh signifikan terhadap permintaan kredit.

Pasha (2009) menganalisis penawaran dan permintaan kredit serta identifikasi peluang ekspansi pembiayaan kredit sektoral di wilayah kerja KBI Malang dengan menggunkan model persamaan simultan. Data yang digunakan dalam penelitian ini merupakan data panel pada tahun 2002 hingga 2007 di delapan daerah kabupaten/kota di wilayah kerja KBI Malang. Hasil penelitian menunjukkan bahwa kapasitas kredit dan Non Performing Loan (NPL) berpengaruh signifikan terhadap penawaran. Sedangkan tingkat bunga acuan tidak berpengaruh signifikan pada penawaran kredit. Arah hubungan NPL menunjukkan tanda positif. Hubungan positif ini menggambarkan adanya kecenderungan perbankan di wilayah kerja KBI Malang untuk menigkatkan laju pertumbuhan kredit sebagai upaya jangka pendek untuk meredam pertumbuhan rasio NPL disamping dalam jangka panjang melakukan upaya penyelesaian kredit bermasalah. Sementara dari sisi permintaan, PDRB dan inflasi berpengaruh signifikan dengan arah yang sesuai hipotesis yaitu PDRB berpengaruh positif dan inflasi berpengaruh negatif.

Penelitian tentang keterkaitan penyaluran dana perbankan dengan kondisi makroekonomi dilakukan oleh Talavera et al. (2006). Penelitian tersebut mengkaji keterkaitan antara perilaku penyaluran kredit bank dan ketidakpastian makroekonomi yang terjadi di Ukraina periode tahun 2003 kuartal pertama sampai tahun 2005 kuartal ketiga. Model yang digunakan adalah ekulibrium parsial dinamik dengan variabel yang digunakan adalah: rasio kredit terhadap modal, rasio dana pihak ketiga terhadap modal, dan natural log modalsendiri, sedangkan indikator ketidakpastian makroekonomi yang digunakan adalah M1, M2, Consumer Price Index (CPI), serta Producer Price Index (PPI). Hasil penelitiannya menunjukkan bahwa perbankan di Ukraina menurunkan penawaran kreditnya jika ketidakpastian peubah makroekonomi meningkat, demikian pula sebaliknya, jika ketidakpastian makroekonomi menurun maka penawaran kredit perbankan meningkat. Implikasi kebijakan dari hasil penelitian tersebut adalah penurunan penawaran kredit akan menurunkan investasi agregat, yang seterusnya memperbesar fluktuasi makroekonomi.

Gambacorta (2004) membahas tentang efektifitas jalur pinjaman 
perbankan (bank lending channel) untuk meneliti reaksi perbankan terhadap perubahan kebijakan moneter. Model ekonometrika yang digunakan mengakomodir interaksi antara indikator kebijakan moneter dengan karakteristik khusus perbankan. Pertumbuhan kredit dipengaruhi oleh perubahan tingkat bunga yang dapat dikontrol oleh otoritas moneter, dan dari hasil interaksinya dengan karakteristik khusus perbankan yaitu: ukuran bank, likuiditas, dan kapitalisasi modal. Regresi juga memasukkan pengaruh inflasi dan pertumbuhan GDP untuk mengkontrol efek dari sisi permintaan.

Penelitian untuk mengidentifikasi dampak shock penawaran kredit terhadap makroekonomi dilakukan oleh Peek dan Tootell (2000). Variabel yang digunakan dalam penelitian ini yaitu melibatkan rating skor tingkat kesehatan bank CAMEL (Capital, Assets, Management, Earnings, dan Liquidity) untuk memproksikan penawaran kredit. Hasil penelitian tersebut menyebutkan meningkatnya tingkat kesehatan bank, akan meningkatkan pertumbuhan GDP riil secara signifikan. Semakin sehat bank akan meningkatkan investasi barang-barang. Dampak perubahan tingkat kesehatan bank signifikan dalam memengaruhi GDP riil. Penelitian tersebut secara garis besar menunjukkan bahwa kondisi perbankan sanggup mempengaruhi kondisi makroekonomi.

Beik dan Aprianti (2013) menganalisis faktor-faktor yang memengaruhi pembiayaan bank syariah pada sektor pertanian. Penelitian ini membagi faktor-faktor yang memengaruhi pembiayaan sektor pertanian pada perbankan syariah melalui tiga indikator. Pertama, indikator makroekonomi dengan variabel inflasi. Kedua, indikator makro perbankan dengan variabel Dana Pihak Ketiga (DPK), Equivalent Rate
Pembiayaan, Equivalent Rate DPK, Suku Bunga Kredit, dan NPF. Ketiga, indikator instrument moneter dengan variabel bonus SBIS dan suku bunga SBI. Metode yang digunakan dalam penelitian ini adalah VECM. Hasil penelitian menunjukkan bahwa bonus SBIS, bunga SBI, Equivalent Rate pembiayaan, Equivalent Rate DPK memengaruhi pembiayaan pertanian pada jangka panjang secara positif dan signifikan sementara jumlah DPK dan suku bunga bank konvensional berpengaruh negatif pada pembiayaan pertanian. Inflasi dan NPF tidak berpengaruh pada pembiayaan sektor pertanian baik dalam jangka pendek maupun jangka panjang.

Qolby (2013) menganalisis faktorfaktor yang memengaruhi pembiayaan perbankan syariah di Indonesia. Metode analisis yang digunakan dalam penelitian ini adalah Vector Error Correction Model dengan menggunakan data statistic perbankan syariah dari Januari 2007 hingga September 2013. Hasil penelitian menunjukkan bahwa dalam jangka pendek DPK berpengaruh positif dan signifikan, SWBI berpengaruh negatif dan signifikan sedangkan ROA tidak berpengaruh signifikan pada pembiayaan. Dalam jangka panjang, DPK, SWBI dan ROA berpengaruh signifikan terhadap pembiayaan perbankan syariah. Secara simultan semua variabel independen yang digunakan dalam penelitian ini yaitu DPK, SWBI, dan ROA dalam jangka pendek dan jangka panjang memiliki pengaruh yang signifikan terhadap pembiayaan yang disalurkan perbankan syariah.

Selanjutnya penelitian yang dilakukan Nugroho (2009) terhadap pembiayaan perbankan syariah pada beberapa faktor yang diteliti menggunakan metode VAR-VECM. Variabel yang digunakan dalam penelitian 
diklasifikasikan menjadi beberapa kategori yaitu kinerja internal bank syariah, instrumen moneter syariah, kondisi makroekonomi, kinerja industri perbankan, dan pasar modal syariah. Variabel yang digunakan dalam penelitian yaitu variabel kredit bank konvensional dan kondisi makroekonomi yang direpresentasikan dengan indeks produksi industri dan Jakarta Islamic Index digunakan sebagai faktor yang memengaruhi permintaan pembiayaan perbankan syariah. Sementara faktor yang memengaruhi pembiayaan dari sisi penawaran adalah kondisi internal perbankan dengan proksi Non Performing Financing (NPF), Return on Asset (ROA), dan Sertifikat Wadiah Bank Indonesia (SWBI). Hasil penelitian menunjukkan bahwa dalam jangka panjang pembiayaan bermasalah dan kredit bank umum signifikan mempengaruhi pembiayaan perbankan syariah. Guncangan dari pembiayaan bermasalah, SWBI, kredit bank umum, indeks produksi industri, dan Jakarta Islamic Index direspon permanen negatif oleh pembiayaan, sedangkan guncangan pada laba per aset, DPK, dan pembiayaan sendiri, direspon permanen positif oleh pembiayaan. Berdasarkan kontribusi dinamis masing-masing peubah, peubah yang paling besar menjelaskan variabilitas pembiayaan adalah pembiayaan bermasalah.

Penelitian Widyastuti dan Anwar (2009) mengenai penggunaan variabelinstrumen moneter syariah dalam menganalisis kinerja perbankan syariah menggunakan metode VAR. Variabel yang digunakan dalam penelitian ini yaitu jumlah DPK, pembiayaan, aset, NPF, SBIS dan volume transaksi dalam PUAS. Hasil menunjukkan bahwa dampak yang ditimbulkan akibat transaksi instrumen moneter syariah terhadap kinerja perbankan syariah berhubungan positif dengan aset dan dana pihak ketiga, serta berhubungan negatif dengan pembiayaan dan Non Performing Financing.

Pada penelitian mengenai pembiayaan bagi hasil pada perbankan syariah, Sujatna (2007) membagi faktorfaktor yang memengaruhi pembiayaan dalam dua kategori yaitu faktor internal dan faktor eksternal. Faktor internal adalah faktor-faktor yang berasal dari kondisi di dalam bank syariah itu sendiri seperti rasio keuangan bank syariah dan nisbah bagi hasil. Sementara faktor eksternal adalah faktor-faktor yang berasal dari luar perbankan syariah seperti kondisi makroekonomi dan suku bunga kredit bank konvensional.

Berdasarkan penelitian terdahulu yang menjadi rujukan, terlihat sudah banyak penelitian yang dilakukan untuk menganalisis pembiayaan perbankan syariah dan kredit perbankan konvensional di Indonesia. Sedangkan penelitian yang menganalisis pembiayaan perbankan syariah pada sektor konstruksi masih belum ada. Perbedaan penelitian ini dengan penelitianpenelitian sebelumnya adalah sektor yang dipilih dalam penelitian ini yaitu sektor konstruksi. Pada penelitian ini menganalisis faktor-faktor yang memengaruhi pembiayaan dankredit sektor konstruksi pada dua jenis perbankan, yaitu perbankan syariah dan konvensional. Selain itu penelitian ini juga menganalisis faktor-faktor yang memengaruhi pembiayaan dan kredit sektor konstruksi pada 33 provinsi di Indonesia. Metode penelitian yang digunakan dalam penelitian ini yaitu Vector Error Correction Model (VECM) dan model panel data. Penelitian ini juga menggunakan variabel-variabel yang digunakan pada penelitian yang dirujuk namun mengalami pengembang- 
an dan penyesuaian sesuai variabel pada sektor konstruksi.

\section{Kerangka Pemikiran Operasional}

Keterkaitan antara perumusan masalah, tujuan penelitian dan metode penelitian dapat dilihat dari kerangka pemikiran operasional yang tersaji pada Gambar 4. Berdasarkan teori dan penelitian-penelitian terdahulu, maka permasalahan pada penelitian ini akan coba dijawab dengan menggunakan pendekatan model Vector Error Correction untuk menjawab permasalahan pertama dan meng-gunakan pendekatan panel data untuk menjawab permasalahan kedua. Secara sistematis kerangka pemikiran operasional dapat dijelaskan sebagai berikut:

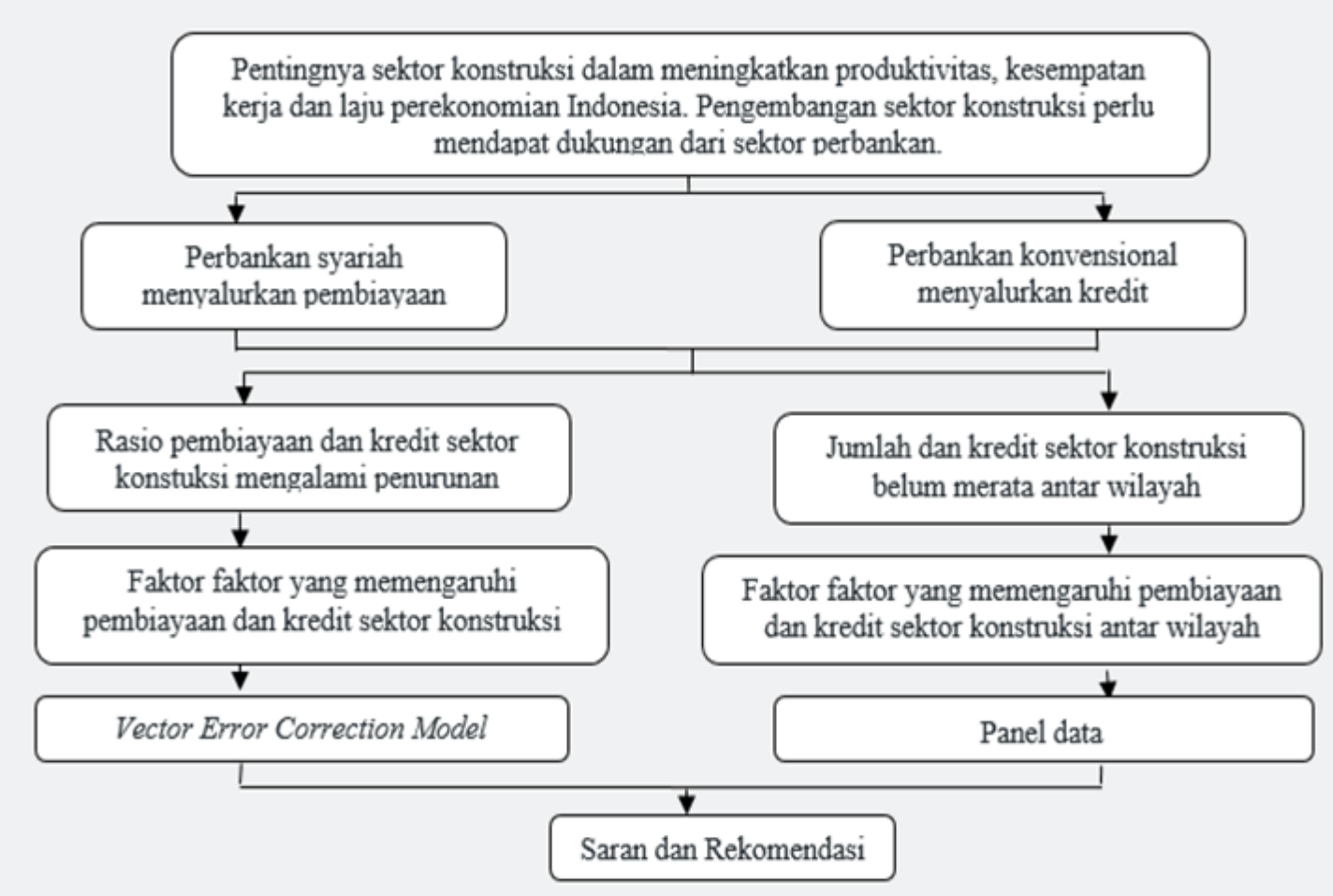

Gambar 4 Kerangka pemikiran operasional

\section{Hipotesis Penelitan}

Berdasarkan landasan teori dan penelitian-penelitian terdahulu, maka hipotesis penelitian untuk menjawab tujuan yaitu sebagai berikut:

Variabel Dana Pihak Ketiga, Equivalent Rate Pembiayaan (suku bunga Kredit), bonus Sertifikat Bank Indonesia Syariah (suku bunga Sertifikat Bank Indonesia), dan Indeks Harga Perdagangan Besar sektor konstruksi memiliki hubungan positif, sedangkan variabel persentase pembiayaan bermasalah dan Indeks
Harga Konsumen memiliki hubungan negatif dalam memengaruhi jumlah pembiayaan (kredit) sektor konstruksi pada perbankan syariah (konvensional) di Indonesia.

Faktor-faktor yang memengaruhi pembiayaan dan kredit sektor konstruksi antar wilayah di Indonesia yaitu besarnya Dana Pihak Ketiga (DPK), persentase pembiayaan bermasalah, tingkat inflasi daerah, Pendapatan Domestik Regional Bruto (PDRB) sektor konstruksi dan pendapatan per kapita pada masing-masing wilayah. 


\section{METODE PENELITIAN}

\section{Jenis dan Sumber Data}

Penelitian ini menggunakan data sekunder. Untuk menjawab permasalahan pertama menggunakan data time series dengan frekuensi bulanan dari Januari 2006 sampai dengan Desember 2014. Untuk menjawab permasalahan kedua, menggunakan data panel dengan frekuensi tahunan, dari tahun 2009 sampai tahun 2013 dengan memasukkan data dari 33 provinsi di Indonesia. Data bersumber dari publikasi Otoritas Jasa Keuangan dan Bank Indonesia serta data dari Badan Pusat Statistika (2015). Penelitian ini juga menggunakan data pelengkap lainnya dari literatur-literatur yang berkaitan, jurnal, buku dan media internet.

\section{Metode Analisis dan Pengolahan Data}

Penelitian ini menggunakan metode analisis yang bersifat deskriptif,

\begin{tabular}{|c|c|c|c|c|c|c|}
\hline \multicolumn{4}{|c|}{$\Delta \mathrm{LN} \_\mathrm{PKt}$} & $\left.\alpha_{10}\right]$ & & \\
\hline \multicolumn{4}{|c|}{$\Delta \mathrm{LN} \_$DPKst } & $\alpha_{20}$ & & \\
\hline \multicolumn{4}{|c|}{$\Delta \mathrm{LN} \_\mathrm{IHKt}$} & $\alpha_{30}$ & & \\
\hline \multicolumn{4}{|c|}{$\Delta \mathrm{ERPt}$} & $\alpha_{40}$ & + & \\
\hline \multicolumn{4}{|c|}{$\triangle$ PERSENTASE_NPFt } & $\alpha_{50}$ & & \\
\hline \multicolumn{4}{|c|}{$\Delta \mathrm{BSBISt}$} & $\alpha_{60}$ & & \\
\hline \multicolumn{4}{|c|}{$\Delta \mathrm{LN}$ _IHPB_KONSTt } & $\left.\alpha_{70}\right\rfloor$ & & \\
\hline$x_{11}$ & $\alpha_{12}$ & $\alpha_{13}$ & $\alpha_{14}$ & $\alpha_{15}$ & $\alpha_{16}$ & $\alpha$ \\
\hline$\alpha_{21}$ & $\alpha_{22}$ & $\alpha_{23}$ & $\alpha_{24}$ & $\alpha_{25}$ & $\alpha_{26}$ & $\alpha$ \\
\hline$\alpha_{31}$ & $\alpha_{32}$ & $\alpha_{33}$ & $\alpha_{34}$ & $\alpha_{35}$ & $\alpha_{36}$ & \\
\hline$\alpha_{41}$ & $\alpha_{42}$ & $\alpha_{43}$ & $\alpha_{44}$ & $\alpha_{45}$ & $\alpha_{46}$ & \\
\hline$x_{51}$ & $\alpha_{52}$ & $\alpha_{53}$ & $\alpha_{54}$ & $\alpha_{55}$ & $\alpha_{56}$ & \\
\hline$\alpha_{61}$ & $\alpha_{62}$ & $\alpha_{63}$ & $\alpha_{64}$ & $\alpha_{65}$ & $\alpha_{66}$ & \\
\hline & $\alpha_{72}$ & $\alpha_{73}$ & $\alpha_{74}$ & $\alpha_{75}$ & $\alpha_{76}$ & \\
\hline
\end{tabular}

Untuk menjawab permasalahan pertama dalam menganalisis faktorfaktor yang memengaruhi kredit sektor konstruksi perbankan konvensional, penelitian ini menggunakan pendekatan dan kuantitatif. Alat analisis yang digunakan untuk menjawab permasalahan pertama dalam penelitian ini adalah metode Vector Autoregression (VAR) apabila data stasioner dan tidak terkointegrasi kemudian dilanjutkan dengan metode Vector Error Correction Model apabila data stasioner dan terdapat kointegrasi. Alat analisis yang digunakan untuk menjawab permasalahan kedua menggunakan analisis regresi panel data. Perangkat lunak yang digunakan untuk proses pengolahan adalah Microsoft Excel 2007 dan Eviews 6.

\section{Model Penelitian}

Untuk menjawab permasalahan pertama dalam menganalisis faktorfaktor yang memengaruhi pembiayaan sektor konstruksi perbankan syariah, penelitian ini menggunakan pendekatan VAR/VECM. Model persamaan VECM dalam bentuk notasi matriks yang digunakan adalah sebagai berikut:
VAR/VECM. Model persamaan VECM dalam bentuk notasi matriks yang digunakan adalah sebagai berikut (Enders, 2004; Firdaus, 2011). 


\begin{tabular}{|c|c|c|c|c|c|c|c|c|c|}
\hline \multicolumn{4}{|c|}{$\Delta \mathrm{LN} \_\mathrm{CKt}$} & {$\left[\alpha_{10}\right]$} & & & & & \\
\hline \multicolumn{4}{|c|}{$\Delta \mathrm{LN} \_$DPKkt } & $\alpha_{20}$ & & & & & \\
\hline \multicolumn{4}{|c|}{$\Delta \mathrm{LN} \_\mathrm{IHKt}$} & $\alpha_{30}$ & & & & & \\
\hline \multicolumn{4}{|c|}{$\Delta \mathrm{SBKt}$} & $=\alpha_{40}$ & + & & & & \\
\hline \multirow{2}{*}{\multicolumn{4}{|c|}{$\begin{array}{c}\Delta \text { PERSENTASE_NPLt } \\
\Delta \text { SBIt }\end{array}$}} & $\alpha_{50}$ & & & & & \\
\hline & & & & $\alpha_{60}$ & & & & & \\
\hline \multicolumn{4}{|c|}{ [ $\Delta$ LN_IHPB_KONSTt } & $\left\lfloor\alpha_{70}\right\rfloor$ & & & & & \\
\hline$\Gamma_{11}^{\alpha}$ & $\alpha_{12}$ & $\alpha_{13}$ & $\alpha_{14}$ & $\alpha_{15}$ & $\alpha_{16}$ & $\alpha_{17}$ & $\left.\alpha_{18}\right]$ & $\Delta \mathrm{LN}_{-} \mathrm{CK}_{\mathrm{t}-1}$ & $\Gamma_{1 t} e_{1}$ \\
\hline$\alpha_{21}$ & $\alpha_{22}$ & $\alpha_{23}$ & $\alpha_{24}$ & $\alpha_{25}$ & $\alpha_{26}$ & $\alpha_{27}$ & $\alpha_{28}$ & $\Delta \mathrm{LN}_{-} \mathrm{DPKk} \mathrm{t}_{\mathrm{t}-1}$ & $e_{2 t}$ \\
\hline$\alpha_{31}$ & $\alpha_{32}$ & $\alpha_{33}$ & $\alpha_{34}$ & $\alpha_{35}$ & $\alpha_{36}$ & $\alpha_{37}$ & $\alpha_{38}$ & $\Delta \mathrm{LN}_{-} \mathrm{IHK}_{\mathrm{t}-1}$ & $e_{3 t}$ \\
\hline$\alpha_{41}$ & $\alpha_{42}$ & $\alpha_{43}$ & $\alpha_{44}$ & $\alpha_{45}$ & $\alpha_{46}$ & $\alpha_{47}$ & $\alpha_{48}$ & $\Delta \mathrm{SBK}_{\mathrm{t}-1}$ & $+e_{4 t}$ \\
\hline$\alpha_{51}$ & $\alpha_{52}$ & $\alpha_{53}$ & $\alpha_{54}$ & $\alpha_{55}$ & $\alpha_{56}$ & $\alpha_{57}$ & $\alpha_{58}$ & $\triangle$ PERSENTASE_NPL $L_{\mathrm{t}-1}$ & $e_{5 t}$ \\
\hline$\alpha_{61}$ & $\alpha_{62}$ & $\alpha_{63}$ & $\alpha_{64}$ & $\alpha_{65}$ & $\alpha_{66}$ & $\alpha_{67}$ & $\alpha_{68}$ & $\Delta \mathrm{SBI}_{\mathrm{t}-1}$ & $e_{6 t}$ \\
\hline$\alpha_{71}$ & $\alpha_{72}$ & $\alpha_{73}$ & $\alpha_{74}$ & $\alpha_{75}$ & $\alpha_{76}$ & $\alpha_{77}$ & $\left.\alpha_{78}\right\rfloor$ & $\Delta \mathrm{LN}_{-} \mathrm{IHPB} \_\mathrm{KONST}_{\mathrm{t}-1}$ & $t_{7 t}$ \\
\hline
\end{tabular}

Tabel 1 Keterangan persamaan VECM

\begin{tabular}{lll}
\hline \multicolumn{1}{c}{ Variabel pada perbankan syariah } & Variabel pada perbankan konvensional & Satuan \\
\hline Pembiayaan konstruksi (PK) & Kredit Konstruksi (CK) & Miliar Rp \\
Dana Pihak Ketiga (DPKs) & Dana Pihak Ketiga (DPKk) & Miliar Rp \\
Persentase Non Performing Financing & Persentase Non Performing Loan & Persen \\
(NPF) & (NPL) & \\
Bonus SBIS (BSBIS) & Suku bunga SBI (SBI) & Persen \\
Indeks Harga Perdagangan Besar & Indeks Harga Perdagangan Besar & Indeks \\
Konstruksi (IHPB) & Konstruksi (IHPB) & \\
Indeks Harga Konsumen (IHK) & Indeks Harga Konsumen (IHK) & Persen \\
Equivalent rate pembiayaan (ERP) & Suku bunga kredit (SBK) & Persen \\
Error term (sisaan) $\mathrm{e}_{1} \mathrm{t}$ & Error term (sisaan) $\mathrm{e}_{1} \mathrm{t}$ & \\
\hline
\end{tabular}

Untuk menjawab permasalahan kedua dalam menganalisis faktor-faktor yang memengaruhi pembiayaan sektor konstruksi perbankan syariah antar wilayah penelitian ini menggunakan pendekatan panel data. Model persamaan yang digunakan adalah sebagai berikut:

$$
\begin{aligned}
Y_{i t}= & \alpha_{0}+\alpha_{1} \ln \_D P K S_{i t}+\alpha_{2} N P F_{i t}+\alpha_{3} \text { INF }_{i t}+\alpha_{4} \text { ln_PDRB_Konst }_{i t} \\
& +\alpha_{5} \ln _{-} \text {PDRB_Perkapita } i t \\
i t & \varepsilon_{i t}
\end{aligned}
$$

Untuk menjawab permasalahan kedua dalam menganalisis faktor-faktor yang memengaruhi kredit sektor konstruksi perbankan konvensional antar wilayah, penelitian ini menggunakan pendekatan panel data. Model persamaan yang digunakan adalah sebagai berikut:

$$
\begin{aligned}
Y_{i t}= & \alpha_{0}+\alpha_{1} \ln \_D P K K_{i t}+\alpha_{2} \mathrm{NPL}_{i t}+\alpha_{3} \mathrm{INF}_{i t}+\alpha_{4} \mathrm{In} \_ \text {PDRB_Konst }_{i t} \\
& +\alpha_{5} \ln _{-} \mathrm{PDRB}_{-} \mathrm{Perkapita}_{i t}+\varepsilon_{i t}
\end{aligned}
$$


Tabel 2 Keterangan persamaan Y_it

\begin{tabular}{|c|c|c|}
\hline Kode & Variabel pada perbankan Syariah & $\begin{array}{l}\text { Variabel pada perbankan } \\
\text { konvensional }\end{array}$ \\
\hline $\mathrm{Y}$ & $\begin{array}{l}\text { Variabel dependen (jumlah } \\
\text { pembiayaan konstruksi Ln_PKit ) }\end{array}$ & $\begin{array}{l}\text { Variabel dependen (kredit } \\
\text { konstruksi CKit ) }\end{array}$ \\
\hline $\mathrm{X}$ & 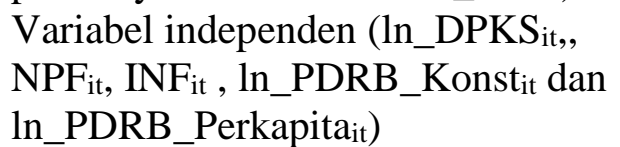 & $\begin{array}{l}\text { Variabel independen (ln_DPKK }{ }_{\text {it }} \text {, } \\
\text { NPL }_{\text {it, INF }} \text { It, ln_PDRB_Konst, dan } \\
\text { ln_PDRB_Perkapita) }\end{array}$ \\
\hline I & Individu ( $\mathrm{N}=33$ provinsi) & Individu ( $\bar{N}=33$ provinsi) \\
\hline $\mathrm{T}$ & $\begin{array}{l}\text { Periode waktu ( } \mathrm{T}=5 \text { tahun, } 2009 \\
\text { sampai dengan 2013) }\end{array}$ & $\begin{array}{l}\text { Periode waktu ( } T=5 \text { tahun, } 2009 \\
\text { sampai dengan 2013) }\end{array}$ \\
\hline$\varepsilon$ & Komponen error & Komponen error \\
\hline
\end{tabular}

Faktor-Faktor yang memengaruhi Pembiayaan dan Kredit Sektor Konstruksi pada Perbankan Syariah dan Konvensional (Analisis VAR/VECM)

Langkah pertama dalam mengestimasi model VAR/VECM adalah uji stasioneritas data dengan metode Augmented Dickey Fuller (ADF) test. Hasil pengujian kestasioneritasan data menunjukkan bahwa semua variabel telah stasioner di first difference. Berdasarkan uji stabilitas VAR yang dilakukan menunjukkan bahwa nilai modulus dari seluruh roots memiliki nilai modulus kurang dari satu, sehingga dapat disimpulkan bahwa model VAR yang digunakan dalam penelitian ini telah stabil pada lag optimalnya.

Berdasarkan hasil uji Johanssen's Trace Statisctic, terdapat persamaan kointegrasi dalam model yang digunakan. Persamaan kointegrasi ini menunjukkan bahwa diantara variabelvariabel yang diuji memiliki hubungan kombinasi lini-ar yang bersifat stasioner (kointegrasi), sehingga model VECM dapat dilakukan dalam penelitian ini, dilanjutkan dengan analisis impuls response function (IRF).

Hasil penelitian pada analisis VECM perbankan syariah menunjukkan bahwa variabel jumlah Dana Pihak Ketiga perbankan syariah (DPKs), Indeks Harga Perdagangan Besar sektor konstruksi (IHPB_Konst), dan bonus Sertifikat Bank Indonesia Syariah (BSBIS) signifikan positif dalam memengaruhi jumlah pembiayaan sektor konstruksi perbankan syariah, sedangkan variabel Persentase Non Performing Financing, Indeks Harga Konsumen (IHK) dan Equivalent rate pembiayaan sektor konstruksi (ERP) siginifikan negatif dalam memengaruhi jumlah pembiayaan sektor konstruksi perbankan syariah.

Hasil penelitian pada analisis VECM Perbankan konvensional menunjukkan bahwa variabel jumlah Dana Pihak Ketiga perbankan konvensional (DPKk), Indeks Harga Perdagangan Besar sektor konstruksi (IHPB_Konst), dan Suku Bunga Kredit (SBK) signifikan positif dalam memengaruhi jumlah kredit sektor konstruksi perbankan konvensional, sedangkan variabel Persentase Non Performing Loan, dan Indeks Harga Konsumen (IHK) siginifikan negatif dalam meme-ngaruhi jumlah kredit sektor konstruksi perbankan konvensional. 
Tabel 3 Hasil estimasi VECM terhadap pembiayaan dan kredit sektor konstruksi perbankan syariah dan konvensional

\begin{tabular}{lcc}
\hline \multicolumn{1}{c}{ Peubah pada Analisis } & \multicolumn{2}{c}{ VECM Jangka Panjang } \\
\cline { 2 - 3 } VECM & Perbankan Syariah & t-statistik \\
LN_DPKS & 4,586641 & {$[-7,23567]^{*}$} \\
LN_IHPB_KONST & 1,073241 & {$[-9,08243]^{*}$} \\
PERSENTASE_NPF & $-0,012993$ & {$[3,82554]^{*}$} \\
LN_IHK & $-3,731081$ & {$[7,38415]^{*}$} \\
ERP & $-0,090562$ & {$[4,25209]^{*}$} \\
BSBIS & 0,292302 & {$[-7,43853]^{*}$} \\
Cointeq & 0,004759 & {$[0,07110]$} \\
\hline & & {$[-6,16686]^{*}$} \\
LN_DPKK & Perbankan Konvensional & {$[-4,55212]^{*}$} \\
LN_IHPB_KONST & 2,568836 & {$[3,51424]^{*}$} \\
PERSENTASE_NPL & $-0,0481810$ & {$[3,06714]^{*}$} \\
LN_IHK & $-6,018220$ & {$[-5,07812]^{*}$} \\
SBK & 0,167183 & {$[-0,88653]$} \\
SBI & 0,017792 & {$[-3,19331]^{*}$} \\
Cointeq & $-0,164679$ & \\
\hline Ket : -) * siginifikan pada taraf nyata 5\% & \\
$\quad-)$ nilai t-ADF untuk nilai kritis 5\% sama dengan 1,96
\end{tabular}

Menurut hasil analisis VECM variabel Dana Pihak Ketiga (DPK) direspon secara positif oleh pembiayaan dan kredit sektor konstruksi. Perbankan sebagai lembaga intermediasi yang bertugas menghimpun dana dalam bentuk simpanan dan menyalurkan dalam bentuk kredit dan bentuk bentuk lainnya. Dana-dana yang dihimpun dari masyarakat yang kemudian disebut dana pihak ketiga merupakan salah satu sumber dana terbesar bank. Hal ini menunjukkan ketika terjadi peningkatan jumlah dana pihak ketiga akan meningkatkan sumber pendanaan bagi perbankan, sehingga bank tersebut dapat meningkatkan peranan bank dalam menyalurkan pembiayaan ataupun kredit, termasuk didalamnya pembiayaan dan kredit untuk sektor konstruksi.
Selanjutnya variabel Indeks Harga Perdagangan Besar sektor konstruksi direspon secara positif oleh pembiayaan dan kredit sektor konstruksi. Hal ini dikarenakan ketika sektor konstruksi dalam kondisi yang baik maka akan meningkatkan persepsi bank terhadap prospek usaha sektor konstruksi. Sehingga ketika IHPB_Konst meningkat maka penyaluran dana untuk pembiayaan dan kredit sektor konstruksi akan meningkat.

Variabel persentase pembiayaan dan kredit bermasalah sektor konstruksi direspon secara negatif oleh jumlah pembiayaan dan kredit perbankan sektor konstruksi. Hal ini dikarenakan karena semakin tinggi pembiayaan bermasalah dari sektor konstruksi maka akan menyebabkan dana perbankan menjadi tidak dapat berputar dari satu nasabah 
ke nasabah lain, karena terjadi kemacetan pada pembiayaan dan kredit tersebut. Pembiayaan bermasalah yang tinggi menyebabkan bank harus membentuk cadangan penghapusan yang lebih besar. Hal ini juga dapat menurunkan minat bank untuk menyalurkan pembiayaan dan kredit pada sektor konstruksi dan mengalihkan untuk pembiayaan dan kredit pada sektor lain dengan tingkat NPF/NPL yang lebih rendah.

Variabel IHK direspon secara negatif oleh pembiayaan dan kredit sektor konstruksi perbankan. Hal ini dikarenakan ketika terjadi kenaikan pada indeks harga konsumen menunjukkan tingkat inflasi yang tinggi maka kondisi perekonomian berada pada kondisi yang tidak stabil maka akan berpengaruh negatif pada kondisi perbankan.

Variabel pada ERP ber-pengaruh secara negatif terhadap pembiayaan sektor konstruksi perbankan syariah dan variabel pada SBK berpengaruh secara positif terhadap kredit sektor konstruksi perbankan konvensional.

Variabel pada BSBIS berpengaruh secara positif terhadap pembiayaan sektor konstruksi perbankan syariah dikarenakan ketika Bonus yang didapat dari Sertifikat BI Syariah mengalami peningkatan maka penerimaan perbankan syariah akan mengalami penambahan sehingga penyaluran dana untuk pembiayaan akan meningkat, termasuk untuk pembiayaan sektor konstruksi. Sedangkan variabel SBI bepengaruh positif namun belum signifikan dalam memengaruhi kredit pada sektor konstruksi perbankan konvensional.

\section{Faktor-Faktor yang Memengaruhi Pembiayaan dan Kredit Sektor Konstruksi Perbankan Syariah dan Konvensional Antar Wilayah (Analisis Panel Data)}

Penelitian yang bertujuan untuk menganalisis faktor-faktor yang memengaruhi jumlah pembiayaan dan kredit sektor konstruksi antar wilayah ini menggunakan metode panel dengan jumlah cross section 33 provinsi di Indonesia dalam waktu 5 tahun sejak tahun 2009 hingga 2013. Variabel pembiayaan dan kredit sektor konstruksi dijadikan sebagai variabel dependen. Sedangkan variabel-variabel independen yang diuji berpengaruh tidaknya terhadap jumlah pembiayaan dan kredit sektor konstruksi bank syariah antara lain Dana Pihak Ketiga, inflasi, Pendapatan Domestik Regional Bruto sektor konstruksi, Pendapatan per kapita, dan pembiayaan bermasalah (NPF/NPL).

Pengolahan data dengan metode panel pada dasarnya dilakukan dengan melakukan beberapa uji untuk mengetahui model panel mana yang terbaik menggambarkan data. Uji Chow dan Hausman dilakukan untuk menguji apakah model terbaik adalah model Pooled Least Square, model fixed effects, dan model random effects.

Uji Hausman dilakukan untuk memilih model FEM dan REM. Hipotesis yang digunakan dalam Uji Hausman yaitu H0: REM dan H1: FEM. Hasil uji Hausman menunjukkan nilai probabilitas yang lebih besar dari alpha $5 \%$. Hal ini berarti kesimpulan yang diambil adalah tidak tolak H0 (terima H0) dan model yang dipilih adalah Random Effect Model (REM) pada kedua persamaan baik persamaan pada 
perbankan syariah maupun konvensional

Tabel 4 Hasil Panel Data pada Perbankan Syariah dan Konvensional

\begin{tabular}{lccrr}
\hline Variable & Coefficient & Std. Error & t-Statistic & \multicolumn{1}{c}{ Prob. } \\
\hline INF & $-0,004913$ & 0,022988 & $-0,213704$ & 0,8311 \\
LN_DPK & 0,769592 & 0,117100 & 6,572102 & $0,0000^{*}$ \\
LN_PDRB_KONST & 0,516225 & 0,193785 & 2,663908 & $0,0085^{*}$ \\
LN_PDRB_PERKAPITA & $-0,413079$ & 0,438197 & $-0,942679$ & 0,3473 \\
PERSENTASE_NPF & 0,074900 & 0,022043 & 3,397848 & $0,0009^{*}$ \\
C & $-2,690599$ & 3,192541 & $-0,842777$ & 0,4006 \\
\hline & Perbankan Konvensional & & \\
INF & 0,014845 & 0,012652 & 1,173349 & 0,2424 \\
LN_DPK & 0,968466 & 0,106201 & 9,119153 & $0,0000^{*}$ \\
LN_PDRB_KONSTRUK & & & \\
SI & $-0,106643$ & 0,106738 & $-0,999106$ & 0,3193 \\
LN_PDRB_PERKAPITA & 0,312531 & 0,182357 & 1,713843 & $0,0885^{* *}$ \\
PERSENTASE_NPL_KO & & & \\
NST & $-0,006796$ & 0,003737 & $-1,818679$ & $0,0708^{* *}$ \\
C & $-5,251831$ & 1,256280 & $-4,180463$ & 0,0000 \\
\hline$*)$ signifikan pada taraf nyata 5\% & & & \\
**) signifikan pada taraf nyata 10\% & & &
\end{tabular}

Model REM yang dihasilkan dalam penelitian pada persamaan perbankan syariah memiliki nilai $R$ squared sebesar $51.35 \%$. Hal ini menunjukkan bahwa sebesar $51.35 \%$ keragaman variabel dependen dapat dijelaskan oleh variabel independen di dalam model, dan selebihnya dijelaskan di luar model. Sedangkan pada model REM yang dihasilkan dalam penelitian pada persamaan perbankan konvensional memiliki nilai $R$-squared sebesar 70,66\%. Hal ini berarti bahwa sebesar $70,66 \%$ keragaman variabel dependen dapat dijelaskan oleh variabel independen di dalam model, dan selebihnya dijelaskan di luar model.

Nilai probabilitas $\mathrm{F}$ statistic sebesar 0,000 yang kurang dari alpha 5\% berarti bahwa keragaman variabel independen telah dapat menjelaskan variabel dependen. Selanjutnya dilakukan uji-t untuk melihat secara parsial variabel-variabel apa saja yang berpengaruh secara signifikan terhadap pembiayaan dan kredit sektor konstruksi perbankan syariah dan konvensional

Variabel DPK masing masing perbankan berpengaruh signifikan positif terhadap pembiayaan konstruksi perbankan syariah dan kredit sektor konstruksi pada taraf nyata 5\%. Hal ini menunjukkan ketika terjadi peningkatan jumlah dana pihak ketiga akan meningkatkan sumber pendanaan bagi perbankan, sehingga bank tersebut dapat meningkatkan peranan bank dalam menyalurkan pembiayaan atau-pun kredit, termasuk di dalamnya pembiayaan dan kredit untuk sektor konstruksi.

Variabel PDRB sektor konstruksi berpengaruh signifikan positif terhadap pembiayaan konstruksi perbankan syariah antar wilayah pada taraf nyata $5 \%$.

Variabel NPF berpengaruh posi-tif dalam memengaruhi pembiayaan 
konstruksi perbankan syariah. Hal ini bisa disebabkan oleh beberapa faktor, dari faktor internal bank misalnya perbankan memberikan kebijakan dengan penambahan volume kredit sehingga non performing loan (NPL) menjadi turun. Variabel persentase NPL berpengaruh negatif dalam mempengaruhi kredit sektor konstruksi perbankan konvensional.

\section{KESIMPULAN DAN SARAN}

\section{Kesimpulan}

Berdasarkan hasil penelitian maka diperoleh simpulan sebagai berikut:

1. Faktor yang memengaruhi pembiayaan dan kredit sektor konstruksi di Indonesia yaitu Dana Pihak Ketiga, Indeks Harga Perdagangan Besar, Bonus Sertifikat Bank Indonesia Syariah (suku bunga Sertifikat bank Indonesia), persentase pem-biayaan bermasalah, Indeks Harga Konsumen dan Equivalent Rate pembiayaan (suku bunga kredit).

2. Faktor yang memengaruhi pembiayaan dan kredit sektor konstruksi antar wilayah di Indonesia yaitu Dana Pihak Ketiga, PDRB sektor konstruksi, PDRB perkapita dan persentase pembiayaan bermasalah.

\section{Saran}

\section{Adapun saran yang dapat diberikan yaitu:}

1. Sektor perbankan sebagai lembaga intermediasi hendaknya menyalurkan dana dalam bentuk pembiayaan/kredit pada sektor riil khususnya sektor konstruksi dengan proporsi yang semakin ditingkatkan karena dapat memberi manfaat yang besar dalam membangun infrastruktur sehingga dapat meningkatkan produktivitas, kesempatan kerja dan laju ekonomi.
2. Penyaluran dana oleh perbankan syariah dan konvensional hendaknya dapat lebih ditingkatkan untuk wilayah Timur Indonesia

\section{DAFTAR PUSTAKA}

Barajas A, Ralph C, Raphael E, Heiko H. 2010. Recent Credit Stagnation in Mena Region: What to Expect? What Can Be Done? IMF Working Paper WP/10/219.

Beik IS, Aprianti. 2013. Analisis Faktor-faktor yang Memengaruhi Pembiayaan Syariah untuk Sektor Pertanian di Indonesia. Jurnal Agro Ekonomi. Volume 31, Nomor 1, Tahun 2013.

BI (Bank Indonesia). 2015. Statistik Perbankan Indonesia http://www.bi.go.id. [2015 Mei 21].

BPS (Badan Pusat Statistika). 2015. http://www.bps.go.id [2016 Februari 22]

Boediono, 1998. Ekonomi Moneter, Seri Sinopsis Pengantar llmu Ekonomi No.5, Yogyakarta : BPFE - UGM.

Enders W. 2004. Applied Econometric Time Series "2th ed". New York (US): University of Alabama.

Firdaus M. 2011. Aplikasi Ekonometrika untuk data panel dan time series. Jakarta: IPB Press.

Gambacorta, L. 2004. Inside the Bank Lending Channel. European Economic Review. www.elsevier.com/locate/econbas e.

Kasmir. 2008. Dasar-dasar Perbankan. Jakarta: Raja Grafindo

Mallick dan Mahalik. 2008. Constructing the economy: the role of construction sector in India's growth. 
Muhammad. 2005. Manajemen Bank Syariah. Yogyakarta: UPP AMP YKPN.

Nugroho R. 2009. Analisis faktor faktor penentu pembiayaan perbankan syariah di Indonesia [tesis]. Bogor (ID): Institut Pertanian Bogor.

[OJK] Otoritas Jasa Keuangan.2016 [Internet diunduh 2016 Februari 22]. Tersedia pada: http://www.ojk.go.id. Jakarta: OJK

Ozcusa dan Akbostanci. 2012. An empirical analysis of the banking channel in Turkey. Turkey: Economic research center working papers in economics 12/05.

Pasha R. 2009. Analisis Penawaran dan Permintaan Kredit Serta Identifikasi Peluang Ekspansi Pembiayaan Kredit Sektoral di Wilayah Kerja KBI Malang. Jurnal Keuangan dan Perbankan. Vol 13 (1) :148-164

Peek R dan Tootell. 2009. Identifying the macroeconomic effect on loan supply shocks. Boston. Tersedia pada: http;//www.papers.ssrn.com

Poghosyan T. 2010. Slowdown of Credit Flows in Jordan in the Wake of the Global Financial Crisis: Supply or Demand Driven?. IMF Working Paper WP/10/1256, November 2010.

Pohan, Aulia. 2008. Kerangka Kebijakan Moneter dan
Implementasinya di Indonesia. Jakarta : Rajawali Pers.

Qolby ML. 2013. Faktor-faktor yang Mempengaruh Pada Pembiayaan Perbankan Syariah di Indonesia Tahun 2007-2013. Economics Development Analysis Journal. Vol 2 (4) : 367-383.

Reed, E.W. 1989. Commercial Banking. New Jersey:Prentice-Hall.

Soemitra A. 2009. Bank dan Lembaga Keuangan Syariah. Jakarta (ID): Kencana.

Sujatna Y. 2007. Analisis Faktor Eksternal dan Internal yang Memengaruhi Pembiayaan Bagi Hasil (Studi Kasus Bank Syariah Mandiri). [Tesis]. Depok (ID) : Universitas Indonesia.

Syafii, A.M. 2001. Bank Syariah: Dari Teori ke Praktik. Jakarta(ID): Gema Insani.

Talavera O, Tsapin A, Zhould O. 2006. Macroeconomic uncertainty and bank lending : the case of Ukraine. Germany: German Institute for Economic Research, 637.

Widyastuti dan Anwar. 2009. Penggunaan variabel instrument moneter syariah untuk menganalisis kinerja perbankan syariah [jurnal]. Jakarta (ID): Akuntabilitas:102. 